\title{
Flexural Strength Analysis of Styrofoam Concrete Hollow Panel Walls Incorporated with High Volume Fly Ash
}

\author{
Mochamad Solikin*, Alfian Nur Zaini, Budi Setiawan, Ali Asroni \\ Faculty of Engineering, Universitas Muhammadiyah Surakarta (UMS), Surakarta, Indonesia
}

Received February 25, 2020; Revised May 19, 2020; Accepted May 29, 2020

Copyright $(2020$ by authors, all rights reserved. Authors agree that this article remains permanently open access under the terms of the Creative Commons Attribution License 4.0 International License

\begin{abstract}
Purpose: One of the innovations needed to create lightweight wall is possible by using Styrofoam as a partially fine aggregate substitution. This study was conducted to study the flexural strength of Styrofoam lightweight concrete panel walls with a high-volume fly ash content in a square column connection. Methodology: The size of the wall panel used is $120 \times 30 \times 10 \mathrm{~cm}$ with 10 x $10 \mathrm{~cm}$ square column holes as support on both sides. In the centre of the wall panel, four square holes with a dimension of $18 \times 4 \mathrm{~cm}$ were created. The variations of fine aggregate replacement with Styrofoam were $50 \%$ and $60 \%$ by the volume of fine aggregate, while the use of Fly ash is $50 \%$ as partially cement substitution. SCC (Self Compacting Concrete) method was used to manufacture this kind of concrete. Results: The results of Slump Flow T50 test for $50 \%$ and $60 \%$ Styrofoam variations are $64 \mathrm{~cm}$ and $59 \mathrm{~cm}$, while the concrete weight-volumes are 1387.7 $\mathrm{kg} / \mathrm{m}^{3}$ and $1259.4 \mathrm{~kg} / \mathrm{m}^{3}$. Compressive strength test for both variations are $42.62 \mathrm{Kg} / \mathrm{cm}^{2}$ and $31.71 \mathrm{~kg} / \mathrm{cm}^{2}$. Stiffness values for both variations are $1434.7 \mathrm{~N} / \mathrm{mm}$ and $1125 \mathrm{~N} / \mathrm{mm}$. This study also analysed the maximum length of the panel wall in which for $50 \%$ Styrofoam variation is 4 $\mathrm{m}$ and $60 \%$ Styrofoam variation is $3.2 \mathrm{~m}$. Applications/ Originality/ Value: Research on Styrofoam concrete hollow panel walls incorporated with high volume fly ash is significant since it opens the possibility to reduce the Styrofoam waste.
\end{abstract}

Keywords Styrofoam, Lightweight Panel, Flexural Strength, Self-Compacting Concrete, Slump Flow

\section{Introduction}

The wall is one of the important elements in a high rise building or house. The wall is non-structural component in the building but the wall has an important role such as room separator and protection from weather. In general, the walls are constructed using red bricks or concrete bricks, but the process requires a long time and requires a lot of workers. So, there are many innovations and creative ideas to solve it. One of the innovations is to make a panel- wall which is casted prior instalment to the construction site. According to Supribadi (1986), concrete wall panels are concrete that is moulded into panel blocks of the preferred size. The advantage of wall panels is more efficient in installation time because the installation is easier in comparison to brick, so that it will shorter the construction duration and reduce the number of human resources in its installation. Previous research about panel wall using thin concrete board and Styrofoam reinforced with bamboo reinforcement has been proven to be an alternative building element for masonry block wall, especially in high rise buildings or earthquake-prone areas (Hatta, 2006).

Wall panel is non-structural element; therefore, it is possible to uses lightweight concrete to produce the wall. According to Tjokrodimulja (1996), lightweight concrete has a specific gravity of between $1000-2000 \mathrm{~kg} / \mathrm{m}^{3}$. Constructing lightweight concrete can be accomplished by creating air pores in the concrete and one the pores can be formed by using Styrofoam as substitution of fine aggregates. Lightweight concrete has been studied by Sambodo (2003) by using Styrofoam diameter of $4 \mathrm{~mm}$ cement $350 \mathrm{~kg} / \mathrm{m}^{3}$ and sand $200 \mathrm{~kg} / \mathrm{m} 3$ and it is possible to obtained the specific gravity of 0.718 tons $/ \mathrm{m}^{3}$.

Styrofoam or Polystyrene generally is used as the protector/wrapping of electronic goods and belongs to the category of high molecular weight synthetic polymers. Polystyrene is a material that is quite good in terms of temperature and mechanical but is fragile and soft at temperatures below $100^{\circ} \mathrm{C}$ (Billmeyer, 1984). According to Craword (1998) polystyrene has a specific gravity of 
$1050 \mathrm{~kg} / \mathrm{m}^{3}$, tensile strength of up to $40 \mathrm{MN} / \mathrm{m} \mathrm{2}$, flexural modulus up to $3 \mathrm{GN} / \mathrm{m}^{2}$, shear modulus up to $0.99 \mathrm{GN} / \mathrm{m} 2$, Poisson number 0.33 and granular Styrofoam the density is in the ranges of $13-16 \mathrm{~kg} / \mathrm{m}^{3}$. The advantage of using Styrofoam in concrete that is it has lower density than normal concrete. In casting lightweight concrete Styrofoam, one of the successful methods used in the mixing process is the SCC method because it can overcome the problem of Styrofoam which tends to float on the surface.

SCC (Self Compacting Concrete) is concrete that has a high Slump value and easily to fill up the formwork to do its self-compaction. This concrete utilizes normal concrete mix proportion with addition of Superplasticizer to obtain special workability which allows concrete to flow alone in the mould and fill all spaces or gaps between tight reinforcement by utilizing the concrete's own weight following the principle of Gravity (Ludwig, II -M., Et al. 2001). According to Risdianto (2010), the advantages of SCC concrete can improve workability in concrete so that it can minimize the effort in casting stage.

Superplasticizer is water reducer type admixture which is added to concrete mixture that can reduce water usage by up to $30 \%$ without reducing workability on concrete. Based on the ACI (American Concrete Institute), admixture are other than water, aggregates and hydraulic cement mixed in concrete or concrete that is added before or during mixing. In the research of Kusnadi (2011), the addition of Superplasticizer can increase the value of Slump flow under the same conditions in fresh concrete, and this can increase the compressive strength of concrete. Besides superplasticizer, one of mineral admixture that can be used in concrete productionis Fly Ash.

According to Solikin and Prihantoro (2015), the use of fly ash can reach 50\% HFVA (high volume fly ash concrete) and the compressive strength of HFVA concrete will be comparable to normal concrete at the age of 56 days. Fly ash is a by-product of coal combustion in the furnace of steam power plants that are smooth, round and are pozolanic (SNI 03-6414-2002) however it is belongs to B3 waste (PP No. 85 of 1999). Fly ash as additional material in concrete is considered to be able to improve the quality of concrete in terms of strength, water tightness, and resistance to sulfate and ease of processing. Moreover, Rusyandi (2012) research reveals that fly ash can also be a filler in the manufacture of SCC concrete. From the various ingredients possessed, fly ash has grade levels namely F, C, and $\mathrm{N}$.

From the explanation above, this research will explore further research on Styrofoam concrete wall panel with utilization of high-volume fly ash in a square column connection. To reduce its self-weight, a rectangular hole in the wall of the Styrofoam concrete panel wall are created with dimension of $18 \times 4 \mathrm{~cm}$ with a distance between holes $5 \mathrm{~cm}$. Concrete mix proportion follows previous research (Solikin and Ikhsan, 2018) SCC method was used ac concrete casting method. The variations in the use of Styrofoam as a partial replacement of fine aggregate are $50 \%$ and $60 \%$ of the volume of fine aggregate with a $50 \%$ mixture of Fly ash as a partial replacement of the cement. The panel wall was tested at 56 days. The purpose of this study was to determine the properties of fresh concrete, concrete compressive strength, flexural strength, and the maximum length of Styrofoam concrete panel walls.

\section{Research Method}

The research was conducted at Civil Engineering Laboratory, Universitas Muhammadiyah Surakarta. The research stages started from studying the literature and preparing materials consisting of fine aggregate originating from Mt. Merapi Yogyakarta. Cement (PC) and Fly ash were obtained from the PT. Holcim Yogyakarta Batching Plant. In addition spherical shaped Styrofoam diameter of 3-5 mm was used; wire mesh diameter $3.5 \mathrm{~mm}$ with spacing $5 \mathrm{~cm} \times 5 \mathrm{~cm}$ and Superplasticizer of Visconcrete 10 type which is produced by PT.SIKA were used.

The next step was the fine aggregate testing in consist of specific gravity, mud content, SSD values, and gradation. After getting the material test data, mix proportion of concrete usage was prepared with volume ratio of cement: fine aggregate equal to $1: 3$, cement water factor (fas) value of 0,28 and Superplasticizer additional material $1.5 \%$ of the cement. The composition of concrete mix materials can be viewed in Table 1.

Table 1. Mix design of $1 \mathrm{~m}^{3}$ lightweight Styrofoam concrete

\begin{tabular}{ccc}
\hline Material & $\begin{array}{c}\text { Mix of } \\
\text { Styrofoam } 50 \%\end{array}$ & $\begin{array}{c}\text { Mix of } \\
\text { Styrofoam } 60 \%\end{array}$ \\
\hline Sand $(\mathrm{kg})$ & 772,27 & 617,4 \\
Styrofoam $(\mathrm{kg})$ & 3,67 & 4,41 \\
Portland Cement $(\mathrm{kg})$ & 285 & 285 \\
Fly Ash (kg) & 285 & 285 \\
Water (lt) & 159,74 & 159,74 \\
Superplasticizer (lt) & 5,705 & 5,705 \\
Total (kg) & 1511,89 & 1357,75 \\
\hline
\end{tabular}

After obtaining the required composition, the next step was casting Styrofoam concrete specimens consist of cylindrical concrete specimen diameter of $15 \mathrm{~cm}$ and a height of $30 \mathrm{~cm}$ and Styrofoam lightweight concrete panel wall size of $120 \times 30 \times 10 \mathrm{~cm}$. The panel is reinforced by diameter of $3.5 \mathrm{~mm}$ wire mesh double reinforcement and on both end of the panel a square column of $10 \times 10 \mathrm{~cm}$ was created as support when testing. After removing the specimens from its moulding, the nest stage is water curing of specimen until the day of testing.

\section{Discussion}

\section{Fine Aggregate Testing}

The testing of fine aggregate for this research referred to 
SNI standards and the results can be shown in Table.2.

Table 2. Fine aggregate test results

\begin{tabular}{ccc}
\hline Type of Testing & Results & SNI Standard \\
\hline Organic ingredients & No. 2 & SNI 2816-2014 \\
Saturated Surface Dry & 3,63 & SNI 1970- 2008 \\
(SSD) & $0,82 \%$ & $<5 \%$. SNI 03-4142- 1996 \\
Mud content & $1,01 \%$ & $<5 \%$. SNI 03-1970-2008 \\
$\begin{array}{c}\text { Specific gravity } \\
\text { absorption value }\end{array}$ & $\begin{array}{c}\text { Dearah } \\
\text { Fine aggregate gradation }\end{array}$ & (SNI 03-2847-2002) \\
\hline
\end{tabular}

From the results of the fine aggregate test which is presented in table 2, it can be concluded the sand meet the qualification of SNI as a concrete composition material.

\section{Slump flow T50 testing}

Slump Flow T50 test has purpose to determine the SCC fresh concrete filling ability and the test was conducted based on Internal-Special specifications SKh-I.10.14 Self-Compacting Concrete (SCC) Ministry of PUPR (SKh-1.7.23, 2017). The Slump Flow T50 test conducted by measuring the diameter of fresh concrete distribution after spreading uses Slump Cone test.

Tabel 3. The results of Slump Flow T50 testing

\begin{tabular}{cccc}
\hline No. & $\begin{array}{c}\text { Styrofoam } \\
\text { Usage } \%\end{array}$ & $\begin{array}{c}\text { Slump Flow } \\
\text { T50 Value }(\mathrm{cm})\end{array}$ & $\begin{array}{c}\text { Requirement of } \\
\text { SKh-I.10.14 (cm) }\end{array}$ \\
\hline 1 & $50 \%$ & 64 & $55-85$ \\
2 & $60 \%$ & 59 & \\
\hline
\end{tabular}

From the data in Table 3, slump Flow T50 for both 50\%

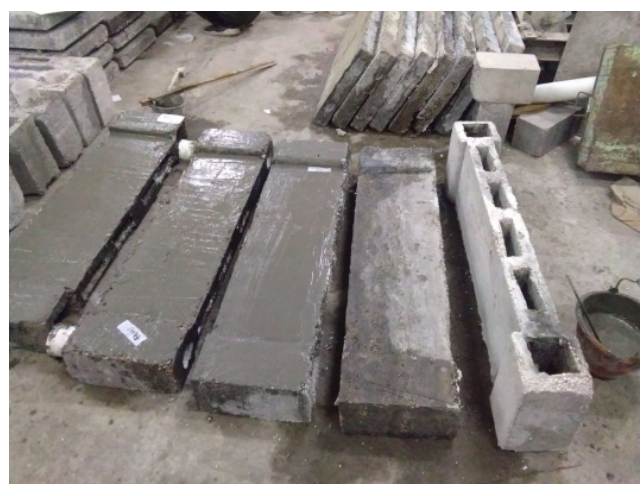

(a) hollow Styrofoam concrete panel wall
Styrofoam content and $60 \%$ Styrofoam content meet the requirements of the Slump flow test standard for SCC. However higher content Styrofoam lead to lower slump flow result at the same usage of $1.5 \%$ superplasticizer. This result is possibly caused by higher gravitational force for $50 \%$ Styrofoam content in which more fine aggregate was used rather than $60 \%$ Styrofoam content the above result is in line with the research of Agus and Slamet (2010) that adding the amount of Polypropylene fibres to the concrete mix will reduce the value of workability.

\section{Styrofoam Concrete Weight-Volume Testing}

The cylinder weight-volume test was completed by weighing the concrete cylinder and then divided by the cylinder mould volume.

From Figure 2, it can be observed that the concrete weight-volume for $50 \%$ Styrofoam is $1387,7 \mathrm{~kg} / \mathrm{m}^{3}$ and decrease to $1259,4 \mathrm{~kg} / \mathrm{m}^{3}$ for $60 \%$ Styrofoam content. The decrease happen due to the increase content of Styrofoam in the concrete mixture that formed a larger number of air cavities in the concrete and lead to the decrease of concrete weight. Therefore, the result makes the Styrofoam concrete is classified as lightweight-Concrete as the weight-volume $<1840 \mathrm{~kg} / \mathrm{m}^{3}$ (SNI 03-2847-2013, 2013). The reduce of weight-volume also found in previous researches, in which additional of Styrofoam will reduce the volume of concrete weight (Priyono, 2014 and Purdianti, 2005)

Figure 1. Spécimens and slump flow test

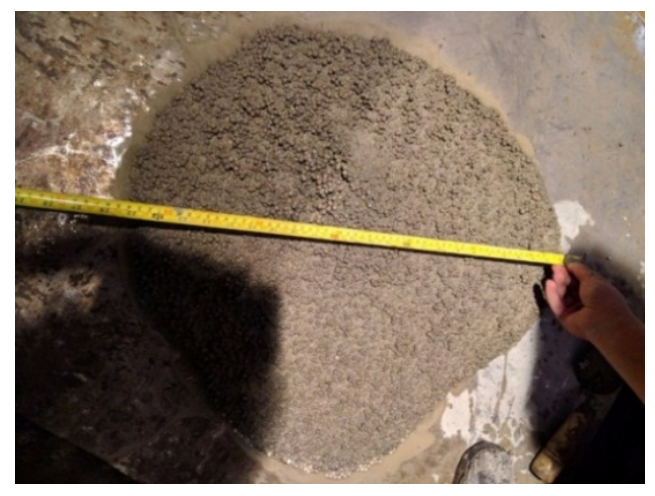

(b) Slump Flow T50 Testing

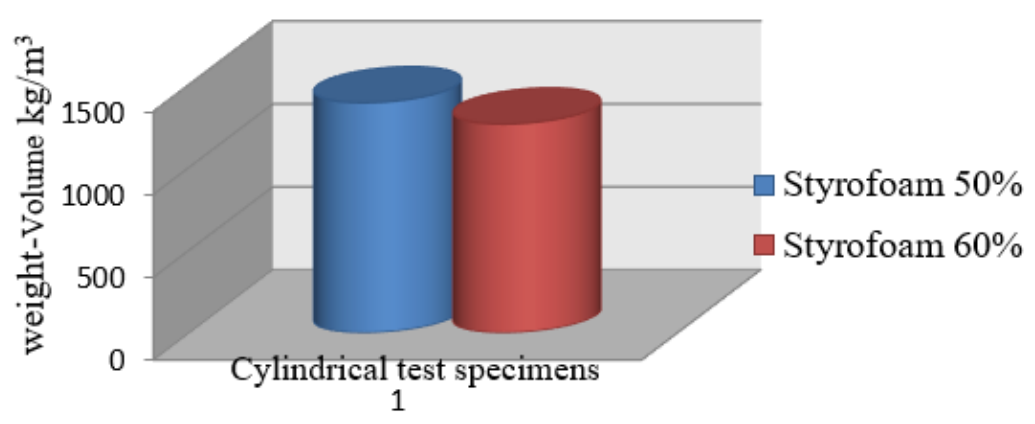

Figure 2. Results of weight-volume testing for lightweight Styrofoam concrete 

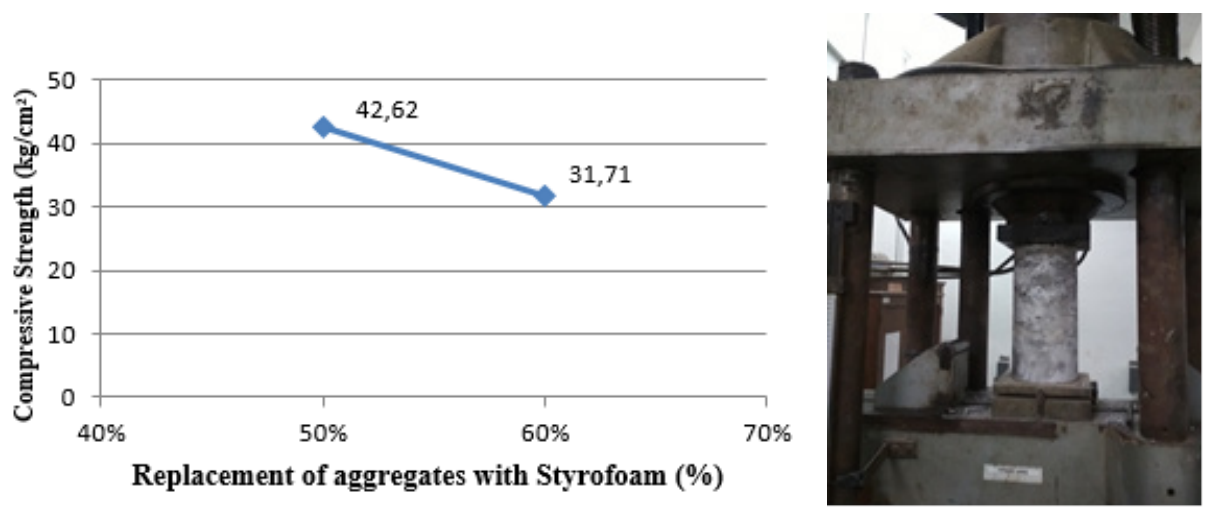

Figure 3. (a) Compressive strength test results, (b) Compressive strength test

\section{Concrete Compressive Strength Testing}

Compressive strength testing in this research was conducted by using Universal Tension Machine (UTM) to apply constant load to cylinder concrete specimen until maximum load. The compressive strength value of concrete cylinders can be determined by the SNI formula 1974-2011.

$$
\mathrm{f}_{\mathrm{c}}=\frac{P}{A}
$$

where:

$$
\begin{aligned}
& f_{c}^{\prime}=\text { Maximum compressive strength }\left(\mathrm{kg} / \mathrm{cm}^{2}\right) \\
& \mathrm{P}=\text { Maximum load }(\mathrm{kg}) \\
& \mathrm{A}=\text { Cylinder surface area }\left(\mathrm{cm}^{2}\right)
\end{aligned}
$$

Figure 4 above demonstrates a decrease in the compressive strength of the cylinder subsequently for $50 \%$ and $60 \%$ Styrofoam content is $42.62 \mathrm{~kg} / \mathrm{cm}^{2}(4.3 \mathrm{MPa})$ and $31.71 \mathrm{~kg} / \mathrm{cm}^{2}(3.2 \mathrm{MPa})$. It was estimated that the reduction in volume of sand followed by the increase of Styrofoam content decrease the compressive strength as air cavity in the concrete becomes greater and lighter. The compressive strength result showed that Styrofoam concrete is non-structural concrete because of $\mathrm{f}^{\prime} \mathrm{c}<20$ MPa (SNI 03-6468-2000).

As a comparison of these results, according to Azhari (2008), the use of $40 \%$ Styrofoam will obtain compressive strength of $7,45 \mathrm{~N} / \mathrm{mm}^{2}$, use of $50 \%$ compressive strength of $4,52 \mathrm{~N} / \mathrm{mm}^{2}$ and the use of $60 \%$ compressive strength of $3,12 \mathrm{~N} / \mathrm{mm}^{2}$. According to Ginting in his study (2007), also stated the addition of Styrofoam to the concrete mix caused a decrease in the compressive strength of concrete from $12,50 \mathrm{MPa}$ to $9,59 \mathrm{MPa}$, or decreased by around $23,28 \%$.

\section{Flexural strength Test of Styrofoam Concrete Panel Walls}

The flexural strength test of the Styrofoam concrete panel wall was proceeded after 56 days of curing by using Loading Frame test, by giving one cantered loading placed in the center of the test specimen.

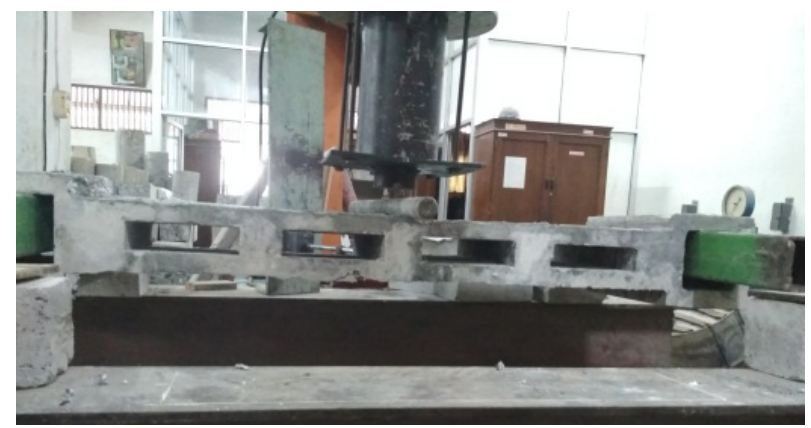

Figure 4. Testing the flexural strength

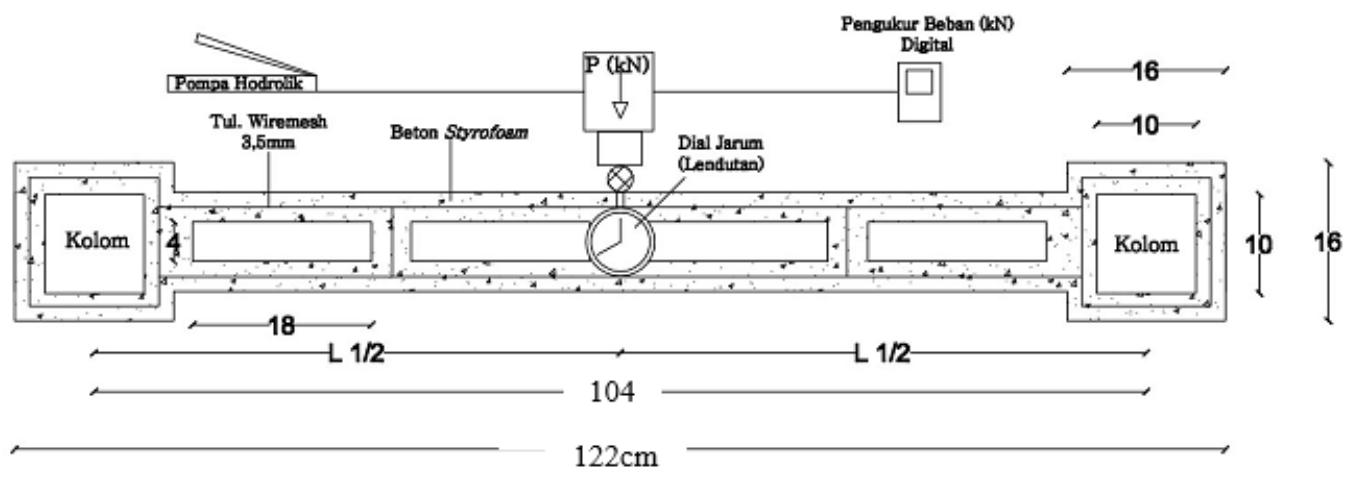

Figure 5. Set up of flexural strength test 


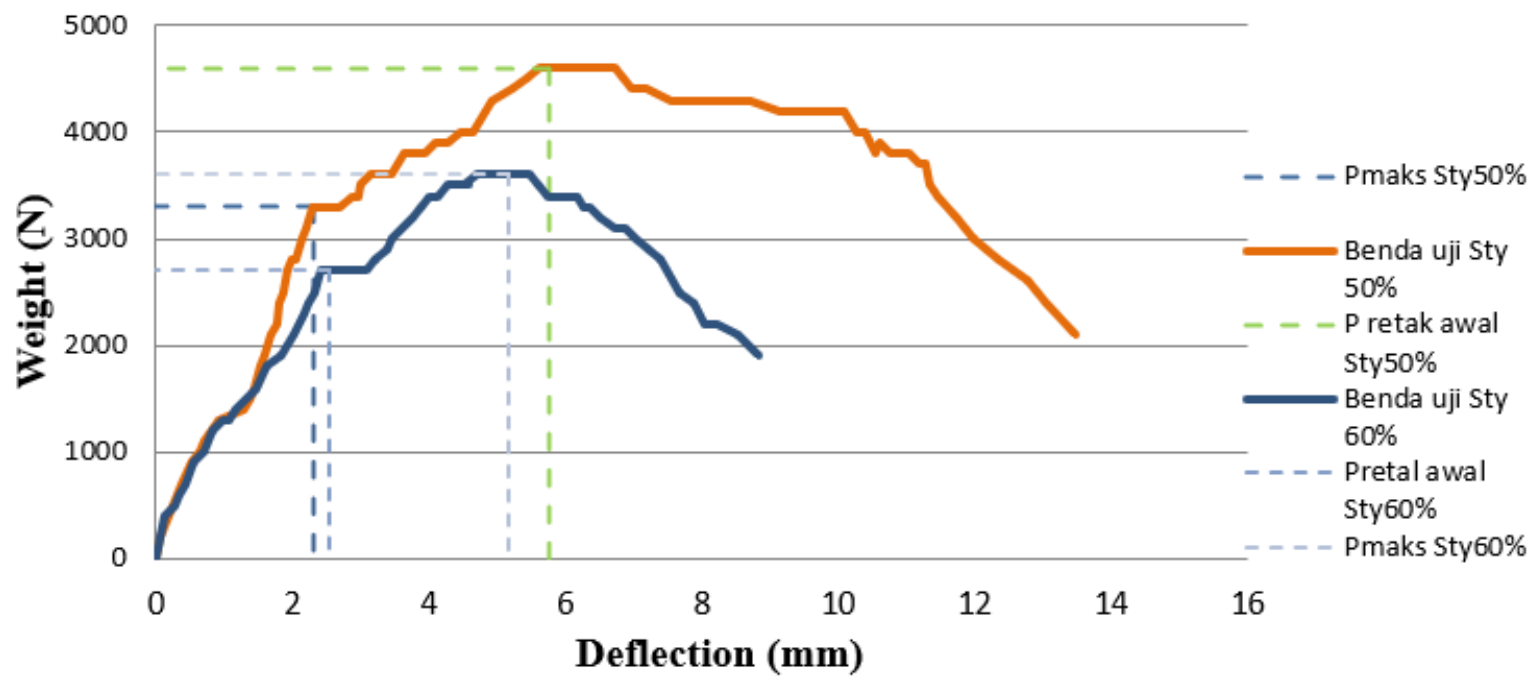

Figure 6. load and deflection of Styrofoam concrete panel walls

The results of testing the flexural strength of the Styrofoam concrete panel walls with a variation of $50 \%$ and $60 \%$ with the Fly ash mixture obtained the relationship between load and deflection values which can be viewed in Figure 6

From Figure 6, it can be conclude that the wall panel with double reinforcement can act as flexural element of and less Styrofoam content lead to higher load capacity of the panel. In addition after the maximum load the panel can perform as ductile structural element as the deflection keep increase after the maximum load.

The maximum load and first crack for 50\% Styrofoam content is $4.6 \mathrm{kN}$ and $3.3 \mathrm{kN}$ in which the deflection reach 5.76 and $2.3 \mathrm{~mm}$. In addition, $60 \%$ Styrofoam content has maximum load and first crack of $3.6 \mathrm{kN}$ and $2.7 \mathrm{kN}$ where the deflection are $4.37 \mathrm{~mm}$ and $2.4 \mathrm{~mm}$ subsequently.

\section{Analyse the maximum length of the walls of Styrofoam concrete panels}

The analysis of the maximum length was intended to acquire the maximum length that can be produce in which on the panel $1 \mathrm{kN}$ load was applied. The formula used in this study was from the research of Sulistyorini (2015), with the formula:

$$
\mathrm{M}=\left(\frac{1}{4} \times P \times L\right)
$$

Where:

$$
\begin{aligned}
& \mathrm{M}=\text { moment }\left(\mathrm{kg} / \mathrm{m}^{2}\right) \\
& \mathrm{P}=\mathrm{P} \text { initial cracked } \\
& \mathrm{L}=\text { Long }(\mathrm{m})
\end{aligned}
$$

Table 4. Calculation of the maximum length

\begin{tabular}{ccccc}
\hline $\begin{array}{c}\text { Test } \\
\text { object }\end{array}$ & $\begin{array}{c}\text { P, initial } \\
\text { crack } \\
(\mathrm{kg})\end{array}$ & $\begin{array}{c}\text { Self weight, } \\
\mathrm{q}(\mathrm{kg} / \mathrm{m})\end{array}$ & $\begin{array}{c}\text { Max length } \\
(\mathrm{m})\end{array}$ & $\begin{array}{c}\text { Moment } \\
(\mathrm{kgm})\end{array}$ \\
\hline $\begin{array}{c}\text { Styrofoam } \\
50 \%\end{array}$ & 330 & 38,67 & 4 & 100,65 \\
$\begin{array}{c}\text { Styrofoam } \\
60 \%\end{array}$ & 270 & 34,05 & 3,2 & 82,35 \\
\hline
\end{tabular}

From the calculation results, the maximum length of the Styrofoam panel walls for $50 \%$ Styrofoam variations was $4 \mathrm{~m}$ and for Styrofoam variations, $60 \%$ is $3.2 \mathrm{~m}$. Therefore this type of Styrofoam panel walls can be produced to compete in the market as the length of the precast panel walls on the market between 2, $5 \mathrm{~m}-3 \mathrm{~m}$.

\section{Conclusions and Suggestions}

Based on the results of research and discussion that has been conducted, it is obtained several conclusions as follows:

1. The Slump Flow T50 value indicated in the use of Styrofoam $50 \%$ and $60 \%$ is still possible to make SCC concrete.

2. The result of weight volume testing using Styrofoam $50 \%$ and $60 \%$ can produce lightweight concrete while the results of the compressive strength test of Styrofoam concrete are very low and can only be used on non-structural concrete.

3. The results of the analysis of the maximum length calculation on the $50 \%$ Styrofoam variation can produce a length of $4 \mathrm{~m}$ and for the $60 \%$, Styrofoam variation was $3,2 \mathrm{~m}$.

Research on Styrofoam concrete hollow panel walls incorporated with high volume fly ash is significant since it opens the possibility to reduce the Styrofoam waste. In order to contribute more, a further study on the utilization of coarse aggregate in mix proportion and the fire resistance of the Styrofoam concrete needs to be conducted.

\section{Acknowledgement}

The authors would like to express their gratitude to Allah The Most Merciful for the completion of this research. An 
appreciation is also addressed to PT. Holcim Bangun/Concrete Batching Plant Solution Yogyakarta which provided sponsors material for this research. Correspondingly, indebtedness is for the Laboratory of Universitas Muhammadiyah Surakarta which provided facilities and infrastructure for conducting this study.

\section{REFERENCES}

[1] Agus S.,dan Slamet, W.,2010. Efek Penambahan Serat Polyropylene terhadap daya lekat dan kuat lentur pada rehabilitasi strukur beton dengan self compacting repair concrete (SRCM). Fakultas Teknik, Universitas Negeri Yogyakarta, Yogyakarta.

[2] Azhari, 2008. Pemanfaatan Limbah Styrofoam Pada Pembuatan Beton Ringan. Teknik Sipil Universitas Riau, Pekanbaru.

[3] Billmeyer, F.W., 1984, "Textbook of Polimer Scinse", 3rd Edition, John Willey and Sons, inc, Singapore.

[4] BSN, 2008. Cara Uji Slump Beton, SNI 1972:2008, Badan Standarisasi Nasional,Jakarta.

[5] BSN, 2011. Cara Uji Kuat Tekan Beton Dengan Benda Uji Silinder, SNI 1974:2011, Badan Standarisasi Nasional, Jakarta.

[6] Crawford, Roy J. 1998. Plastics Engineering (Therd edition). Oxford, Uk: Butterworth-Heinemann. Hal. 8-9,18-28, 245-351

[7] Departemen Pekerjaan Umum, (2017)."Beton Memadat Sendiri (Self Compacting Concrete)". Spesifikasi Khusus intern-1.10.14. Jakarta.

[8] Fahrudin, Z., 2013.Tinjauan Kuat Lentur Dinding Panel Beton Ringan Menggunakan Campuran Styrofoam dengan Tulangan Kawat Jaring Kassa Welded Mesh, Naskah Publikasi bulan mei 2013, Jurusan Teknik Sipil, Fakultas Teknik, UMS, Surakarta.

[9] Ginting, A., 2007, Pengaruh penambahan Styrofoam terhadap Kuat Tekan Dan Kuat lentur Beton, Jurnal Teknik SKALA Vol.4, No.2, Fakultas Teknik Universitas Muhammadiyah Mataram.

[10] Hatta, M.N. 2006. Uji Kuat lentur Dinding Panel Hardflex dan Styrofoam Dengan Tulangan Bambu, Tugas Akhir, Jurusan Teknik Sipil, Fakultas Teknik, Universitas Muhammadiyah Suakarta (tidak Dipublikasikan).
[11] Kusnadi, Dewi Sulistyorini. (2011)."Pengaruh Penambahan Superplastisizer Terhadap Campuran Beton Ringan Yang Menggunakan Styrofoam”. Jurnal, 3684-9497-1-SM.Ternat e, 2011

[12] Ludwig H. M., Wesise F., Hemrich W., and Ehrlich N. (2001), "Self-Cmpacting Concrete-Principles and Pratice". Investigation into the Basic Mix Formulation, Comparision of SCC and Varios Vibrated Concrites, SCC With Different Filler Components, SCC with Airpores, Stabilization of SCC BFT, 6, 58-67

[13] Noerman, MF., 2017 Pengaruh lapis Styrofoam Pada Plat Beton Bertulangan Bambu Terhadap kekakuan Plat Satu Arah, Jrusan Teknik Sipil, Fakultas Teknik Universitas Brawijaya, Malng.

[14] Prihantoro, T.F., Solikin, M. (2015). "Perkembangan Kuat Tekan Beton Mutu Tinggi dengan Memanfaatkan Teknologi High Volume Fly Ash Concrete". Simposium Nasional RAPI XIV, 301-307

[15] Priyono YP., Nadia., 2014 pengaruh penggunaan styrofoam sebagai pengganti agregat kasar terhadap kuat tekan beton. Teknik sipil universitas muh jakarta,jakarta

[16] Purdianti, A., 2005, Pengaruh Penambahan Styrofoam Terhadap Kuat Tekan Concrete Semen, Skripsi FT UJB, Yogyakarta.

[17] Risdianto. Y., 2010. Penerapan Self Compacting Concrete (SCC) Pada Beton Mutu Normal. WAKTU, 8(2), pp.54-60.

[18] Rusyandi, Kukun, dkk. 2012. Perancangan Beton Self Compacting Concrete (Beton Memadat Sendiri) dengan Penambahan Fly Ash dan Structuro. Jurnal Kontruksi Vol.10 No.1. Sekolah Tinggi Teknologi Garut.

[19] Sambodo, A.A., 2003, Penggunaan Styrofoam untuk Beton Ringan Dengan kandungan Semen $350 \mathrm{~kg} / \mathrm{m}^{3}$, Tugas Akhir urusan Teknik Sipil, Fakultas Teknik, Universitas Gadjah Mada, Yogyakarta

[20] Setiawati, M., 2018, Fly Ash Sebagai Bahan Pengganti Semen Pada Beton, Jurnal.umj.ac.id/index.php/semnastek.

[21] Sugiharto, Handoko, 2001, Penggunaan Fly Ash dan Viscocrete pada Slef Compacting Concrete, Jurnal Dimensi Teknik Sipil Vol.8, UK Petra.

[22] Supribadi, 1986. Dinding Panel Kering (paving Block), Penerbit Erlangga, Jakarta.

[23] Tjokrodimuljo, k., 1996 Teknologi Beton, Jurusan Teknik Sipil, Fakultas Teknik Universitas Gadjah Mada, Yogyakarta. 